\title{
Gambaran Pengetahuan Ibu Tentang MP-ASI di Desa Sindur Cambai Kota Prabumulih Tahun 2019
}

\section{Ana Sapitri}

Akademi Kebidanan Budi Mulia Prabumulih

Informasi Artikel :

Diterima : 17 April 2020

Direvisi : 27 April 2020

Disetujui : 10 Mei 2020

*Korespondensi Penulis : anasapitri6@gmail.com

\section{A B S T R A K}

Makanan pendamping ASI (MP-ASI) harus mulai diberikan ketika bayi tidak lagi mendapat cukup energi dan nutrien dari ASI saja. Untuk kebanyakan bayi, makanan tambahan mulai diberikan pasa usia 6 bulan keatas. Pada usia ini MP-ASI sangat penting untuk menambah energi dan zat gizi yang diperlukan Tujuan penelitian ini untuk mendapatkan gambaran pengetahuan ibu tentang pemberian makanan pendamping ASI pada bayi usia 0 -6 bulan di Desa Sindur Cambai Kota Prabumulih tahun 2019. Jenis penelitian ini adalah penelitian deskriptif. Populasi penelitian ini adalah semua ibu yang memiliki bayi usia 0-6 bulan yang ada di Desa Sindur Cambai pada bulan Juni 2019. Pengambilan sampel dilakukan dengan cara non random dengan tekhnik Accidental Sampling. Tekhnik analisa data dilakukan dengan analisa univariat, analisa ini digunakan untuk memperoleh gambaran distribusi frekuensi dan presentase dari tiap variabel. Hasil penelitian ini menunjukkan bahwa pengetahuan responden tentang makanan pendamping ASI yang baik sebesar $71,4 \%$, pengertian tentang makanan pendamping ASI yang baik sebesar 71,4 \%, tujuan tentang pemberian makanan pendamping ASI yang baik sebesar $77,1 \%$, manfaat tentang pemberian makanan pendamping ASI yang baik sebesar 57,1 \%, dan waktu pemberian makanan pendamping ASI yang baik sebesar 28,6\%. Diharapkan materi makanan pendamping ASI perlu dimasukkan dalam pelajaran tambahan agar mahasiswa mendapat informasi yang benar tentang makanan pendamping ASI.

Kata kunci : : ASI, Makanan Pendamping ASI 
material should be included in additional lessons so that students get the right information about complementary feeding.

Keywords: Breastfeeding, Breastfeeding Food

\section{PENDAHULUAN}

Menyusui adalah proses pemberian susu kepada bayi atau anak kecil dengan air susu ibu (ASI) dari payudara ibu. Bayi menggunakan refleks menghisap untuk mendapatkan dan menelan susu ${ }^{1}$ Makanan Pendamping ASI (MPASI) merupakan makanan lain yang selain ASI. Makanan ini dapat berupa makan yang disiapkan secara khusus atau makanan keluarga yang dimodifikasi. ${ }^{1}$ Menyusui adalah memberikan air susu untuk diminum kepada bayi, dan sebagainya dari buah dada ibu. ${ }^{2}$

Pada umur 0-6 bulan, bayi tidak membutuhkan makanan atau minuman selain ASI. Artinya bayi hanya memperoleh susu ibu tanpa tambahan cairan lain, baik susu formula, madu, air teh. Bayi juga tidak diberi makanan padat lain seperti pisang dan nasi lumat, bubur, susu, biskuit, nasi tim dan lain-lain. Makanan pendamping ASI (MP-ASI) harus mulai diberikan ketika bayi tidak lagi mendapat cukup energi dan nutrien dari ASI saja. Untuk kebanyakan bayi, makanan tambahan mulai diberikan pasa usia 6 bulan keatas. Pada usia ini MP-ASI sangat penting untuk menambah energi dan zat gizi yang diperlukan. ${ }^{3}$

Kenyataannya di lapangan masih banyak ibu yang memberikan MP-ASI pada bayinya meskipun umurnya masih belum mencapai 6 bulan. Padahal apabila memberikan MP-ASI terlalu dini, bayi akan minum ASI lebih sedikit dan ibupun memproduksi lebih sedikit, hingga akan lebih sulit untuk memenuhi kebutuhan nutrisi bayi. Di samping itu resiko infeksi dan diare kemungkinan bisa terjadi. Pemerintah dan organisasi internasional sepakat untuk mempromosikan menyusui sebagai metode terbaik untuk pemberian gizi bayi setidaknya tahun pertama atau bahkan lebih lama lagi. Organisasi tersebut antara lain WHO, American Academy of Pediatrics, dan Departemen Kesehatan.

Adanya informasi yang baru dalam pemberian makanan tambahan yang baru boleh diberikan pada bayi usia 6 bulan ke atas, atau sebaliknya bila pendidikan seseorang rendah kemungkinan akan menghambat seseorang untuk menerima informasi yang baru mengenai pemberian makanan tambahan yang baru boleh diberikan pada bayinya antara usia 6 bulan keatas.

Budaya merupakan kebudayaan dimana kita hidup dan dibesarkan mempunyai pengaruh besar terhadap pembentukan sikap kita4 yang telah melekat pada masyarakat kemungkinan sulit untuk diubah karena kebiasaan yang dilakukan oleh masyarakat sehingga akan merekat pada diri seseorang, termasuk budaya dalam pemberian makanan pendamping bagi bayi yang berumur kurang dari 6 bulan. Dengan memberikan nasi pisang lumat yang sebenarnya tidak dibenarkan karena bayi yang berusia kurang dari 6 bulan kemampuan ususnya atau pencernaannya masih terbatas, sehingga makanan masih belum dapat dicerna dengan baik dan dapat menyebabakan diare maupun alergi. Budaya masyarakat yang memberikan dampak yang negatif dengan adanya MP-ASI yang seharusnya di berikan pada bayi usia 6 bulan keatas. Tetapi sudah di berikan pada usia kurang dari 6 bulan. ${ }^{3}$

Peran keluarga menggambarkan seperangkat perilaku interpersonal sifat kegiatan yang berhubungan dengan individu dalam posisi dan situasi tertentu. ${ }^{4}$ Keberhasilan dalam memberi-kan makanan pada bayi tidak hanya tergantung pada ibu saja, tetapi dukungan dan peran serta keluarga mempunyai peran yang sangat penting dalam pemberian nutrisi pada bayi. Keluarga sebaiknya memahami mengenai MP-ASI, terutama mengenai kapan MP-ASI harus diberikan, jenis, bentuk dan jumlahnya. ${ }^{5}$

Peran keluarga berperan penting bagi pemeliharaan kesehatan keluarga. Keluarga yang terdiri dari ibu, ayah, dan anak harus mempunyai sifat yang positif terhadap situasi dalam keluarga kemungkinan ibu dapat memberikan makanan pendamping secara benar. Dampak apabila pemberian MP-ASI terlalu dini maka bayi akan mendapat zat immun ASI lebih sedikit, sehingga resiko infeksi meningkat. Resiko diare juga meningkat karena makanan tambahan tidak sebersih ASI. Ibu mempunyai resiko lebih tinggi untuk hamil kembali jika jarang menyusui. ${ }^{6}$

Apabila pemberian MP-ASI terlalu lambat maka anak tidak akan mendapatkan makanan ekstra yang dibutuhkan untuk mengisi kesenjangan energi dan nutrien. Anak berhenti pertumbuhannya, atau tumbuh lambat. Pada anak resiko malnutrisi dan defisiensi mikronutrien meningkat. $^{7}$ 
Untuk meningkatkan pengetahuan ibu tentang waktu pemberian MP-ASI dalam hal ini petugas kesehatan khususnya tenaga perawat diharapkan dapat memberikan penjelasan pada orang tua mengenai upaya yang dapat dilakukan untuk memberikan stimulus pada anaknya, sehingga anak tersebut dapat tumbuh dan berkembang secara baik. ${ }^{8}$

Dengan banyaknya faktor yang melatarbelakangi tingginya angka ibu yang memberi MP-ASI pada bayi usia 0-6 bulan, maka peneliti hanya membatasi pada Gambaran pengetahuan ibu tentang pemberian MP-ASI pada bayi usia 0-6 bulan di Desa Sindur Cambai kota Prabumulih Tahun 2019.

\section{METODE PENELITIAN}

Penelitian ini merupakan suatu penelitian survey deskriptif dimana suatu metode yang biasanya bertujuan untuk menggambarkan atau memotret masalah kesehatan yang berkaitan dengan kesehatan penduduk atau orang yang tinggal dalam komunitas tertentu ${ }^{8}$.

Populasi adalah keseluruhan objek penelitian atau objek yang diteliti tersebut. Dalam penelitian ini populasi penelitian adalah semua ibu yang memiliki bayi usia 0-6 bulan di Desa Sindur Cambai Kota Prabumulih tahun 2019. ${ }^{8}$

Teknik Pengumpulan Data yaitu data primer Data diperoleh dari objek penelitian secara langsung dari hasil pengisian kuesioner yang diberikan pada responden dan Data Sekunder Data sekunder diperoleh dari data-data yang berhubungan dengan penelitian yang ada pada bidan dan Kepala Desa, Dinas Kesehatan, Penelusuran buku sumber data dari internet. ${ }^{8}$

Instrumen yang digunakan dalam pengumpulan data adalah berupa kuesioner yaitu merupakan pedoman peneliti dalam melakukan wawancara dari responden. ${ }^{9}$

Analisa univariat dilakukan terhadap tiap variabel dari hasil penelitian untuk menghasilkan distribusi ftrkuensi dan presentase dari tiap variabel adapun variabel independen diteliti yaitu (Pengertian MP-ASI, Tujuan MP-ASI, Manfaat MP-ASI dan Waktu Pemberian MP-ASI), dan variabel dependen yaitu ( MP-ASI ) dalam bentuk tabel. ${ }^{8}$

\section{HASIL DAN PEMBAHASAN}

\section{Hasil Penelitian}

\section{Analisis Univariat}

Analisa ini dilakukan untuk mengetahui distribusi frekuensi variabel dependen variabel adapun variabel independen diteliti yaitu
(Pengertian MP-ASI, Tujuan MP-ASI, Manfaat MP-ASI dan Waktu Pemberian MP-ASI), dan variabel dependen yaitu (Pengetahuan Ibu Tentang MP-ASI ). Hasil penelitian terhadap masing-masing variabel akan diuraikan di bawah ini :

\section{Variabel Dependen}

Tabel 1 Distribusi Frekuensi Responden Berdasarkan Pengetahuan Ibu Tentang Pemberian Makanan Pendamping ASI Di Desa Sindur Cambai Prabumulih Tahun 2019

\begin{tabular}{ccc}
\hline $\begin{array}{c}\text { Pengetahuan } \\
\text { MP-ASI }\end{array}$ & Frekuensi & Persen \\
\hline Baik & 25 & $71,4 \%$ \\
\hline Kurang & 10 & $28,6 \%$ \\
\hline Total & $\mathbf{3 5}$ & $\mathbf{1 0 0}$ \\
\hline
\end{tabular}

Berdasarkan tabel 1 diatas dari 35 responden didapatkan ibu pengetahuan pemberian makanan pendamping ASI baik sebanyak 25 responden ( 71,4\%) dan pemberian makanan pendamping ASI kurang sebanyak 10 responden $(28,6 \%)$.

Variabel Independen

a. Pengertian Makanan Pendamping ASI

Tabel 2 Distribusi Frekuensi Responden Berdasarkan Pengertian Pemberian Makanan Pendamping ASI Di Desa Sindur Cambai Prabumulih Tahun 2019

\begin{tabular}{ccc}
\hline $\begin{array}{c}\text { Pengertian MP- } \\
\text { ASI }\end{array}$ & Frekuensi & Persen \\
\hline Baik & 25 & $71,4 \%$ \\
\hline Kurang & 10 & $28,6 \%$ \\
\hline Total & $\mathbf{3 5}$ & $\mathbf{1 0 0}$ \\
\hline
\end{tabular}

Berdasarkan tabel 2 diatas dari 35 responden didapatkan ibu yang mengetahui pengertian makanan pendamping ASI baik sebanyak 25 responden $(71,4 \%)$ dan kurang sebanyak 10 responden $(28,6 \%)$.

\section{b. Tujuan Pemberian MP-ASI}

Tabel 3 Distribusi Frekuensi Responden Berdasarkan Tujuan Pemberian Makanan Pendamping ASI Di Desa Sindur Cambai Prabumulih Tahun 2019

\begin{tabular}{ccc}
\hline Tujuan MP-ASI & Frekuensi & Persen \\
\hline Baik & 27 & $77,1 \%$ \\
\hline Kurang & 8 & $22,9 \%$ \\
\hline Total & $\mathbf{3 5}$ & $\mathbf{1 0 0}$ \\
\hline
\end{tabular}


Berdasarkan tabel 3 diatas diatas dari 35 responden dapat diketahui bahwa ibu pengetahuan tujuan pemberian makanan pendamping ASI baik sebanyak 27 responden $(77,1 \%)$ dan kurang 8 responden $(22,9 \%)$.

\section{c. Manfaat Pemberian MP-ASI}

Tabel 4 Distribusi Frekuensi Responden Berdasarkan Manfaat Pemberian Makanan Pendamping ASI Di Desa Sindur Cambai Prabumulih Tahun 2019

\begin{tabular}{ccc}
\hline Manfaat MP-ASI & Frekuensi & Persen \\
\hline Baik & 20 & $57,1 \%$ \\
\hline Kurang & 15 & $42,9 \%$ \\
\hline Total & $\mathbf{3 5}$ & $\mathbf{1 0 0}$ \\
\hline
\end{tabular}

Dari Tabel 4 diatas dari 35 responden dapat diketahui bahwa ibu yang pengetahuan tentang manfaat pemberian makanan pendamping ASI baik 20 responden ( $57,1 \%)$ dan kurang 15 responden $(42,9 \%)$.

\section{d. Waktu Pemberian MP-ASI}

Tabel 5 Distribusi Frekuensi Responden Berdasarkan Waktu Pemberian Makanan Pendamping ASI Di Desa Sindur Cambai Prabumulih Tahun 2019

\begin{tabular}{ccc}
\hline $\begin{array}{c}\text { Waktu MP- } \\
\text { ASI }\end{array}$ & Frekuensi & Persen \\
\hline Baik & 10 & $28,6 \%$ \\
\hline Kurang & 25 & $71,4 \%$ \\
\hline Total & $\mathbf{3 5}$ & $\mathbf{1 0 0}$ \\
\hline
\end{tabular}

Dari Tabel 5 diatas dari 35 responden dapat diketahui bahwa ibu yang pengetahuan tentang waktu pemberian makanan pendamping ASI baik sebanyak 10 responden $(28,6 \%)$ dan kurang $(71,4 \%)$.

\section{PEMBAHASAN}

Penelitian ini menggunakan desain Deskriftif yaitu mengambarkan saja tentang pengetahuan ibu yang mempunyai bayi usia 0-6 Bylan mengenai Makanan Pendamping Asi (MPASI), dengan menggunakan Uji-Square serta Pertanyaan sebagai alat yang digunakan untuk mengumpulkan data melalui Angket dan Kuesioner.

\section{Variabel Dependen}

\section{Makanan Pendamping ASI}

Jumlah ibu-ibu yang memiliki bayi usia 0-6 bulan yang memberikan MP-ASI di Desa Karang Raja tahun 2012 dan sekaligus menjadi responden pada penelitian ini berjumlah 35 orang. Dari hasil penelitian responden makanan pendamping ASI yang baik berjumlah 25 orang, sedangkan responden makanan pendamping ASI yang kurang berjumlah 10 orang.

\section{Variabel Independen}

a. Pengertian Makanan Pendamping ASI.

Hasil analisis univariat menunjukkan responden pengertian makanan pendamping ASI baik sebanyak 25 responden $(71,4 \%)$ dan kurang sebanyak 10 responden $(28,6 \%)$. Makanan pendamping ASI (MP-ASI) adalah makanan lain selain ASI. Makanan ini dapat berupa makanan yang disiapkan secara khusus atau makanan yang dimodifikasi.

\section{b. Tujuan Pemberian Makanan Pendamping ASI}

Hasil analisis univariat menunjukkan responden tujuan pemberian makanan pendamping ASI sebanyak 27 responden $(77,1 \%)$ dan kurang sebanyak 8 responden ( $22,9 \%$ ). Tujuan pemberian makanan pendamping ASI adalah untuk menambah energi dan zat-zat gizi yang diperlukan bayi karena ASI tidak dapat memenuhi kebutuhan bayi secara terus menerus. ${ }^{7}$

\section{c. Manfaat Pemberian Makanan Pendamping ASI \\ Hasil analisis unvariat menunjukkan} responden manfaat pemberian makanan pendamping ASI baik sebanyak 20 responden $(57,1 \%)$ dan kurang sebanyak 15 responden $(42,9 \%)$. Manfaat MP-ASI adalah untuk menambah energi dan zat gizi yang diperlukan bayi karena ASI tidak dapat mencukupi kebutuhan bayi secara terus-menerus. Pertumbuhan dan perkembangan anak yang normal dapat diketahui dengan cara melihat kondisi pertambahan berat badan seorang anak tidak mengalami peningkatan, menunjukkan bahwa kebutuhan energi bayi tidak terpenuhi.

\section{d. Waktu Pemberian Makanan Pendamping ASI}

Hasil analisis univariat menunjukkan responden waktu pemberian makanan pendamping ASI baik sebanyak 10 responden $(28,6 \%)$ dan kurang sebanyak 25 responden $(71,4 \%)$. Makanan tambahan harus mulai diberikan ketika bayi tidak lagi mendapat cukup energi dan nutrisi dari ASI saja. Untuk 
kebanyakan bayi, makanan tambahan mulai diberikan pada usia 6 bulan keatas. Pada usia ini otot dan syaraf didalam mulut bayi cukup berkembang untuk mengunyah, menggigit dan memamah.

\section{e. Penelitian Terkait}

Pengetahuan pada dasarnya adalah hasil dari tahu yang terjadi setelah orang melakukan pengindraan terhadap suatu objek tertentu melalui pancaindra manusia, yakni indra penglihatan, pendengaran, penciuman, rasa dan raba. Sebagian besar pengetahuan diperoleh melalui mata dan telinga. Perilaku kesehatan dipengaruhi pula oleh pengetahuan sebagai faktor predisposisi. Jika pengetahuan tentang MP-ASI baik diharapkan pula pada akhirnya perilaku terhadap pemberian MPASI juga baik. ${ }^{9}$

Berdasarkan Survey Kesehatan Rumah Tangga (SKRT) tahun 2005, menyebutkan bahwa kurang lebih $40 \%$ bayi usia kurang dari dua bulan sudah diberi MP-ASI. Disebutkan juga bahwa bayi usia nol sampai dua bulan mulai diberikan makanan pendamping cair (21,25\%), makanan lunak/lembek (20,1\%), dan makanan padat $(13,7 \%)$. Pada bayi tiga sampai lima bulan yang mulai diberi makanan pendamping cair $(60,2 \%)$, lumat atau lembik $(66,25 \%)$, dan padat $(45,5 \%)$.

Dan dari beberapa penelitian dinyatakan bahwa keadaan kurang gizi pada bayi dan anak disebabkan karena kebiasaan pemberian MP-ASI yang tidak tepat dan ketidaktahuan ibu tentang manfaat dan cara pemberian MP-ASI yang benar sehingga berpengaruh terhadap pemberian MP-ASI. ${ }^{1}$

Salah satu faktor penyebab perilaku penunjang orang tua dalam memberikan makanan pendamping ASI pada bayinya adalah masih rendahnya pengetahuan ibu tentang makanan bergizi bagi bayinya.

Yang dimaksud dengan pengetahuan ibu tentang makanan bergizi adalah hasil tahu karena faktor penginderaan terhadap suatu obyek tertentu tentang bahan makanan yang diperlukan dalam satu hari yang beraneka ragam dan mengandung zat tenaga, zat pembangun dan zat pengatur yang dibutuhkan oleh tubuh.

Karena kurangnya pengetahuan yang dimiliki oleh ibu, sehingga banyak bayi yang mengalami gizi kurang. Untuk mencegah terjadinya berbagai gangguan gizi dan masalah psikososial diperlukan adanya perilaku penunjang dari para orang tua, khususnya perilaku ibu dalam memberikan makanan pendamping ASI pada bayinya.

Yang dimaksud dengan pemberian makanan pendamping ASI adalah pemberian makanan tambahan pada bayi setelah bayi berusia 6-24 bulan, jadi selain makanan pendamping, ASI pun harus tetap diberikan pada bayi sampai bayi berusia 2 tahun. ${ }^{9}$

Dan berdasarkan penelitian yang saya lakukan, dinyatakan bahwa di desa Sindur Camba Kota Prabumulih masih banyak ibu yang kurang mengetahui tentang manfaat dan waktu pemberian makanan pendamping ASI pada bayi 0-6 bulan. Sehingga ibu-ibu yang memiliki bayi usia 0-6 bulan diberikan makanan selain ASI.

\section{KESIMPULAN}

Berdasarkan hasil penelitian mengenai gambaran pengetahuan ibu tentang pemberian makanan pendamping ASI yang telah dilakukan dan pembahasan yang dikemukakan dapat ditarik kesimpulan sebagai berikut: Gambaran distribusi frekuensi responden berdasarkan pengetahuan makanan pendamping ASI yang baik sebanyak 25 responden $(71,4 \%)$ dan pengetahuan makanan pendamping ASI yang kurang sebanyak 10 responden $(28,6 \%)$ dan Gambaran distribusi frekuensi responden berdasarkan waktu pemberian makanan pendamping ASI yang baik sebanyak 10 responden $(28,6 \%)$ dan waktu pemberian makanan pendamping ASI yang kurang sebanyak 25 responden $(71,4 \%)$.

\section{DAFTAR PUSTAKA}

1. Nursalam, 2012, Asuhan Keperawatan Bayi Dan Anak, Edisi Pertama, Jakarta: Salemba Medika

2. Ensiklopedia bebas berbahasa, 2019, Pengetahuan diakses (.www. Wikipedia. Co.Id. Diunduh pada 05 Juni 2019).

3. Donna L. Wong, 2008, Buku Ajar Keperawatan Pediatrik, Volume 1, Edisi 6, Jakarta: EGC

4. Dep Kes RI, 2009, Buku Kesehatan Ibu dan Anak, Jakarta: Departemen Kesehatan

5. Suherni dkk, 2009. Perawatan Masa Nifas. Yogyakarta: Fitramaya

6. Herawani, 2012, Pendidikan Perawatan Dalam Kesehatan, Jakarta: ECG 
7. Soekodjo, Notoatmojo. 2012, Metodologi Penelitian Kesehatan, Jakarta: Rineka Cipta

8. Soekidjo, Notoatmojo. 2016, Promosi Kesehatan dan Ilmu Perilaku, Jakarta : Rineka Cipta

9. Suherni dkk, 2009. Perawatan Masa Nifas. Yogyakarta: Fitramaya 
